\title{
Trophic Organization of Fishes in a Coastal Seagrass System
}

\author{
Robert J. Livingston \\ Department of Biological Science, Florida State University, Tallahassee, Florida 32306, USA
}

\begin{abstract}
A long-term (8-y) field study was made concerning the trophic relationships of fishes that occupy shallow coastal grassbeds in the northeast. Gulf of Mexico. Various populations migrate into such areas to nursery during portions of their life histories. Many fishes undergo seasonal progressions of tood preferences that follow species-specific, ontogenetic patterns. While the extent of such dietary successions varies considerably among the 14 species examined, many populations follow developmental progressions that may encompass various trophic levels from herbivory to carnivory. Omnivores are relatively common in the grassbed areas and there was a range of trophic specialization among the fishes examined. Generalized food preferences were often associated with early growth stages; as they matured, various populations became more specialized in their feeding habits. Through treatment of each developmental stage of trophic preference as an individual entity (or 'ontogenetic trophic unit'), it was possible to identify progressions of feeding organization through time. Varying levels of temporal partitioning of food resources were evident. Periodic interspecific overlap of food resources was noted during periods of high productivity. Most grassbed fishes were adapted to extreme seasonal changes in habitat. This adaptation was reflected in observed temporal changes in diet and would explain the difficulty of making direct, linear associations of population distribution with multivariate analyses of specific habitat characteristics. The use of the 'ontogenetic trophic unit' facilitated the examination of the relationships of complex associations of fishes to a highly variable environment.
\end{abstract}

\section{INTRODUCTION}

While food habits of fishes have been studied extensively, specific relationships of trophic interactions, habitat partitioning, and spatial/temporal variability of coastal fishes remain largely undetermined. Trophic 'opportunism' has been emphasized in estuarine and coastal studies (Darnell, 1958, 1961), and evidence exists concerning the importance of omnivory and the lack of distinct trophic levels in such areas resulting from ontogenetic progressions of 'distinct nutritional stages' (Darnell, 1958; Carr and Adams, 1973; Kikuchi and Pérès, 1977; Ross, 1978; Sheridan and Livingston, 1979; Stoner, 1979b). Resource partitioning has been examined in different fish communities (McEachran et al., 1976; Chao and Musick, 1977; Ross, 1977; MacPherson, 1981); however, the research evidence of a relationship between food resources and trophic partitioning (Gascon and Leggett, 1977) remains relatively undeveloped.

There is considerable literature concerning the relationship of food preferences of fishes to variation in habitat and time. Estuarine nectonic food webs have been reviewed by de Sylva (1975). Sheridan (1979) examined the trophic response of estuarine (mud flat) fishes. Coral reef fishes have been analyzed in various ways (Ogden, 1976; Hobson, 1978; Ogden and Lobel, 1978) while Bray and Ebeling (1975) studied the trophic relationships of kelp forest fishes. Representative studies of the offshore feeding relationships of demersal fishes have been carried out by Tyler (1972) and Ross (1977, 1978). The grassbed literature (Brook, 1977; Kikuchi and Pérès, 1977; Stoner, 1979a; Livingston, 1980) also reflects concern for the trophic organization of fishes relative to specific habitat features of the respective systems in question. Despite such attention, there is still no uniform approach to the question of how trophic interactions are related to the dynamic basis of community structure.

This paper examines the trophic response of fishes in coastal seagrass beds in the N.E. Gulf of Mexico with particular attention to ontogenetic progressions of resource utilization by dominant seagrass species through time and the relationship of such trophic stages to key environmental features of the system. 


\section{MATERIALS AND METHODS}

An 8-year (1971-1979) study was conducted in 2 adjacent estuaries in Apalachee Bay along the northwest coast of Florida, USA $\left(30^{\circ} 01^{\prime} \mathrm{N}, 83^{\circ} 56^{\prime} \mathrm{W}\right)$. Seven permanent stations were established in comparable portions of each estuary, and all collections were made in these areas. Background information for this study has been provided by Livingston (1975), Hooks et al. (1976), and Zimmerman and Livingston (1976a, 1976b, 1979).

Field collections of physico-chemical and biological data were taken at the fixed stations during the day on a monthly basis from 1971 through 1979. Surface and bottom water samples were taken with a 1-1 Kemmerer bottle. Transects were devised so that sampling included a range of salinity regimes from the river mouths to the open Gulf of Mexico. Dissolved oxygen and water temperature were measured using a dissolved oxygen meter and a stick thermometer. Such samples were verified with the modified Winkler method (Strickland and Parsons, 1968). Salinity was taken with a temperature-compensated refractometer calibrated periodically with standard sea water. Turbidity was determined with a Hach model 2100-A turbidimeter. Color was measured using an American Public Health Association platinum-cobalt standard test. Light penetration was estimated with a standard Secchi disk. Water depth was measured at each sampling site. Nutrients and productivity (phytoplankton, benthic macrophytes) were analyzed as described by Bittaker (1975). River flow information was provided by the U.S. Geological Survey (Tallahassee, Florida). Regional rainfall data were provided by a local paper-pulp mill.

Five-meter otter trawls $(1.9 \mathrm{~cm}$ mesh wing and body; $0.6 \mathrm{~cm}$ mesh liner) were used for biological sampling seven repetitive $2-\mathrm{min}$ tows were made at each station at speeds approximating 2-2.5 knots. All samples were taken during the day. The number of samples necessary for species accumulation curves exceeding $90 \%$ were determined by methods similar to those described by Livingston et al. (1976a). All animals were preserved immediately in $10 \%$ buffered formalin, sorted, identified to species, counted, and measured (standard length). Detailed descriptions of biological sampling procedures are given by Livingston (1975). A list of the numerically dominant species used in this study is given in Table 1.

Smaller fishes $(<160 \mathrm{~mm})$ were stored in $10 \%$ buffered formalin for trophic studies. The stomachs of larger fishes were immediately dissected out and injected with $10 \%$ buffered formalin. Fishes were placed in 5- and 10-mm size classes depending on species, and food items taken from the stomachs of up to 25 fish in a size class (per station per sampling event) were pooled and preserved in $70 \%$ isopropanol and a dilute solution of rose bengal stain. Adequate food item accumulation per sample was estimated according to established procedures (Livingston et al., 1976a). This analysis was done in conjunction with notations concerning the frequency of 'empty' stomachs so that sampling effort could be established on an empirical basis. It was found that 7 to 15 individuals (depending on species) were adequate for $90 \%$ food item representation. Combined samples representing 15 or more fish were used for all analyses to assure adequate representation by food item although no such assurance was made for the proportionate distribution of such items. Trophic analysis was carried out with 14 numerically abundant species, where enough material was available for 'quantitative' analysis. These species represented over $88 \%$ of the fishes taken during the 8-year study period.

The gravimetric sieve fractionation procedure (Carr and Adams, 1972) was used for stomach content analysis. Contents were washed through a series of sieves of decreasing mesh size $(2.0-0.075 \mathrm{~mm}$ mesh). The contents were identified to species wherever possible. For all statistical analyses, food particles were grouped in mutually exclusive categories (Table 2). The frequency of occurrence of each food type was recorded for each sieve fraction. Because all items in a particular sieve fraction were of comparable size, the relative proportion of each food type was measured directly by counting. After such examination, each sieve fraction was dried $\left(100^{\circ} \mathrm{C}\right)$ for sufficient time to allow a dry weight measurement, and the total contribution of each food type was calculated. The categories 'bivalve mollusks', 'animal remains' (unidentified tissue stained with rose bengal), 'plant remains', 'fish remains', and 'crusta-

Table 1. List of fish species analyzed in the long-term trophic study. The fishes are presented in their general order of abundance during the otter trawl sampling program in the

Econfina and Fenholloway estuaries from 1971 to 1979

\begin{tabular}{|ll|}
\hline Species & Common name \\
\hline Lagodon rhomboides & pinfish \\
Leiostomus xanthurus & spot \\
Bairdiella chrysura & silver perch \\
Monacanthus ciliatus & fringed filefish \\
Diplodus holbrooki & spottail pinfish \\
Syngnathus floridae & dusky pipefish \\
Orthopristis chrysoptera & pigfish \\
Eucinostomus gula & silver jenny \\
Centropristis melana & Gulf black sea bass \\
Monacanthus hispidus & planehead filefish \\
Eucinostomus argenteus & spotfin mojarra \\
Paraclinus fasciatus & banded blenny \\
Syngnathus scovelli & Gulf pipefish \\
Anchoa mitchilli & bay anchovy \\
\hline
\end{tabular}


Table 2. List of general food types found in fish stomachs, and codes used to describe them in presentation of the data. 'Plant remains': unidentified living plant matter; 'detritus': dead organic matter

\begin{tabular}{|c|c|c|c|c|c|}
\hline AP & Appendicularians & DI & Diatoms & NU & Nudibranchs \\
\hline AM & Amphipods & $\mathrm{EC}$ & Echinoderms & OS & Ostracods \\
\hline $\mathrm{BA}$ & Barnacles & $\mathrm{FE}$ & Fish eggs & PL & Polychaete larvae \\
\hline $\mathrm{BC}$ & Bryozoans & FL & Fish larvae & $\mathrm{PO}$ & Polychaetes \\
\hline $\mathrm{BI}$ & Bivalve mollusks & $\mathrm{FO}$ & Foraminiferans & PR & Plant remains \\
\hline NG & Barnacle nauplii & $\mathrm{FP}$ & Fecal pellets & $\mathrm{SC}$ & Scallops \\
\hline $\mathrm{BR}$ & Branchiurans & FR & Fish remains & $\mathrm{SH}$ & Shrimp \\
\hline $\mathrm{CC}$ & Copeods (calanoid and cyclopoid) & GA. & Gastropod mollusks & SL & Spicules \\
\hline $\mathrm{CH}$ & Chaetognaths & $\mathrm{HC}$ & Harpacticoid copepods & SO & Sponge \\
\hline $\mathrm{CJ}$ & Crab juveniles & $\mathrm{HY}$ & Hydroids & $\mathrm{SP}$ & Shrimp postlarvae \\
\hline $\mathrm{CM}$ & Crab megalops & IE & Invertebrate eggs & ST & Stomatopods \\
\hline CR & Crabs & IL & Insect larvae & SY & Syringodium filiforme \\
\hline CS & Crustacean remains & IS & Isopods & TA & Tanaids \\
\hline CT & Chiton & IT & Invertebrate tubules & $\mathrm{TH}$ & Thalassia testudinum \\
\hline $\mathrm{CU}$ & Cumaceans & MY & Mysids & $\mathrm{TR}$ & Trematodes \\
\hline $\mathrm{CZ}$ & Crab zoea & NE & Nematodes & TU & Turbellarians \\
\hline DE & Detritus & NM & Nemerteans & VL & Veliger larvae \\
\hline
\end{tabular}

cean remains' were the only categories not mutually exclusive with other groups. For this analysis, all sieve fractions were totaled for a given sample and dry weight (mg) by item per individual fish was used in all statistical manipulations, which were carried out on combined collections of data (all stations, all times).

Storage, retrieval, and analysis of data were performed with an interactive computer program and the Statistical Package for the Social Sicences (SPSS, Nie et al., 1970). Detailed reviews of the use of such techniques were given by Livingston (1975), Livingston et al. (1978), and Meeter and Livingston (1978). All cluster analyses were run using the 'rho' similarity coefficient (Matusita, 1955; van Belle and Ahmad, 1974). The flexible grouping method with beta $=-0.25$ (Lance and Williams, 1967) was employed as qualified by Sneath and Sokal (1973) and Meeter and Livingston (1978). Groupings were arbitrarily associated at similarity coefficients exceeding 0.80 .

\section{RESULTS}

\section{The 'Ontogenetic Trophic Unit'}

Stoner (1980a) and Livingston (1980) found that Lagodon rhomboides undergoes ontogenetic changes in feeding. Such feeding progressions are temporally stable in terms of the overall pattern in a given area from year to year (Livingston, 1980). There is, in fact, a well ordered progression of changes in food preference by size class (Fig. 1). Early growth stages (11-15 mm $\mathrm{SL}$ ) are largely planktivorous and feed on calanoid and cyclopoid copepods. With growth (16-25 mm SL), the pinfish broadens its diet to a mixture of plankton and benthos as it adds harpacticoid copepods, amphipods, shrimp, and other small invertebrates to its diet. Further growth (26-60 $\mathrm{mm}$ SL) is accompanied by the addition of plant remains and detritus as amphipods become a major food item. Growth from 61 to $120 \mathrm{~mm}$ $\mathrm{SL}$ is accompanied by a second stage of omnivory with

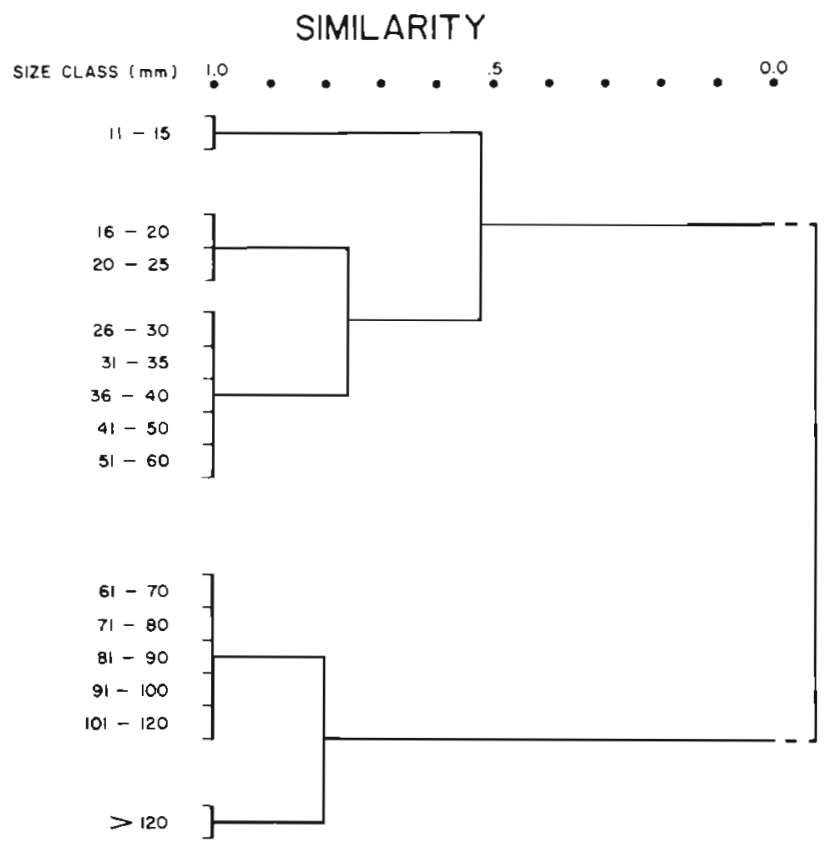

Fig. 1. Cluster analysis of prey similarity among size classes of pinfish (Lagodon rhomboides) taken in Apalachee Bay from 1971 through 1977. Data from the Econfina and Fenholloway estuaries were summed $(\mathrm{N}=4333)$. Ordering of trophic units from individual size classes was based on similarity coefficients greater than 0.80 
increased reliance on plant matter in various forms. The fish also take bivalve mollusks and other benthic invertebrates such as shrimp and harpacticoid copepods. Pinfish that exceed $120 \mathrm{~mm}$ SL are largely herbivorous, feeding mainly on seagrass such as Syringodium filiforme and Thalassia testudinum. In areas devoid of seagrasses there is evidence that bivalve mollusks are taken. While the ontogenetic progression of feeding represents a temporal continuum with considerable overlap between adjacent growth stages and spatial variation in diet specialization, there is a relatively stable pattern of pinfish diet in shallow grassbeds ranging from planktivory and benthic carnivory through 2 stages of omnivory and a final (largely) herbivorous feeding mode. Long-term (year-to-year) analyses indicate that, in a given area, this general feeding pattern did not deviate to any degree throughout the 8-year study period (Livingston, 1980).

A cluster analysis was run on trophic data for each of the 14 fish species and the ontogenetic trophic units were ordered accordingly (Table 3 ). In this way, sizespecific feeding classes were arranged according to similar dietary habits within a given species. There was a range of species-specific feeding patterns, with no uniform pattern among all species. For instance, species such as Anchoa mitchilli (bay anchovy) and Paraclinus fasciatus had no ontogenetic progression of food preferences, and fed in a uniform manner throughout their lives in the estuaries. The relatively high trophic diversity of the bay anchovy indicates that this species is a trophic generalist, while Paraclinus tends to be more specialized in its food preferences. There was a tendency of more generalized feeding at early growth stages of various species. Those populations with relatively complex feeding progressions such as Lagodon rhomboides, Diplodus holbrooki, and Orthopristis chrysoptera tended to be trophic specialists during later growth stages. Overall, these species, together with spot and anchovies, tended to be trophic generalists compared to the monacanthids, syngnathids, and benthic predators (Bairdiella, Centropristis). The total intake per individual tended to increase with the size of the fish. Often the number of food items taken was highest during intermediate stages of growth. Such dietary patterns have been associated with species-specific ontogenetic changes in the morphology of the mouth parts and body dimensions (Stoner and Livingston, unpubl.) and progressive alteration of individual behavioral attributes. This analysis indicates that, despite a broad range of feeding mechanisms associated with developmental changes in individual life history characteristics, there are certain ontogenetic patterns of feeding strategy that are common to disparate populations.

\section{Trophic Organization}

A cluster analysis (Fig. 2) was run using the identified trophic units (Table 3 ) as variables. The trophic organization was clearly divided into 3 major groups. The first such group was composed of planktivorous forms, including early stages of various species; anchovies, spot and the mojarras (Eucinostomus spp.) were represented within Group I at various stages of development. These species fed primarily on copepods (calanoid, cyclopoid, harpacticoid), amphipods, and plant remains or detritus. Early stages of pinfish and spot are late winter feeders that specialize on planktonic copepods. With development, the pinfish broaden their diet to include mixtures of planktonic and benthic copepods, amphipods, and various forms of plant matter as described above. The migrations of pinfish during this trophic stage tend to overlap the late spring migrations of young Orthopristis and early summer peaks of anchovies. With development through the spring, the spot become benthic omnivores. The later stages of mojarra, however, tend to specialize on polychaetes to a greater extent than any other of the species analyzed in this study. Populations of Eucinostomus argenteus reach peak numbers during the summer while E. gula reaches such levels in the fall. These species follow a similar pattern of trophic specialization during development.

The second major trophic grouping is dominated by benthic omnivores and carnivores. Pinfish are abundant during summer and fall months and follow progressive changes from omnivory through herbivory. Diplodus holbrooki is numerically abundant during spring and early summer. This species goes through a series of trophic stages. It feeds on plant remains, harpacticoid copepods, invertebrate eggs, and benthic crustaceans during early stages. There is an increasing dependence on plant remains and hydroids in the more mature fishes. Although these 2 species are spatially and temporally sympatric, there was relatively little dietary overlap. Specific differences in diet appear to be related to differing morphological development (Stoner and Livingston, unpubl.), which appears to be an important feature of differentiation in the developmental stages of food preference in various seagrass fishes. The monacanthids (Monacanthus hispidus, $M$. ciliatus) show taxonomic similarity in their feeding habits; both species are benthic omnivores feeding on combinations of plant remains and small invertebrates such as amphipods, copepods, polychaetes, and bivalve mollusks.

Mature fishes of the third group tend to specialize on crustaceans such as shrimp, crabs, and amphipods. Early growth stages of Orthopristis chrysoptera, Bairdiella chrysura, and Syngnathus floridae feed largely 
Table 3. Results of cluster analysis of stomach content data for 14 fish species taken in Apalachee Bay from 1971 through 1977. The data were collapsed in space and time; functional feeding groups (trophic units) were identified by similarity coefficients exceeding 0.80. Each trophic unit was numbered for use in further analyses. A diversity index (Shannon and Weaver, 1963) was run with the summed (dry weight) data for each trophic unit. The number of food items per number of individuals was determined using methods described by Livingston et al. (1976b)

\begin{tabular}{|c|c|c|c|c|c|c|}
\hline $\begin{array}{l}\text { Ontogenetic } \\
\text { trophic unit }\end{array}$ & & No. & $\begin{array}{c}\text { Intake (mg) } \\
\text { per individual }\end{array}$ & $\begin{array}{l}\text { No. food items } \\
\text { per } 15 \text { indiv. }\end{array}$ & $\begin{array}{l}\text { Shannon } \\
\text { diversity }\end{array}$ & $\begin{array}{l}\text { Number of } \\
\text { fish analyzed }\end{array}$ \\
\hline $\begin{array}{l}\text { Lagodon rhomboides } \\
\text { (pinfish) }\end{array}$ & $\begin{array}{l}-1 \\
-2 \\
-3 \\
-4 \\
-5\end{array}$ & $\begin{array}{l}1 \\
2 \\
3 \\
4 \\
5\end{array}$ & $\begin{array}{r}0.2 \\
0.6 \\
2.2 \\
8.9 \\
47.5\end{array}$ & $\begin{array}{r}7 \\
20 \\
32 \\
27 \\
19\end{array}$ & $\begin{array}{l}1.359 \\
2.303 \\
2.472 \\
2.344 \\
1.713\end{array}$ & $\begin{array}{r}97 \\
322 \\
2950 \\
1279 \\
267\end{array}$ \\
\hline $\begin{array}{l}\text { Leiostomus } \\
\text { xanthurus (spot) }\end{array}$ & $\begin{array}{l}-1 \\
-2 \\
-3 \\
-4\end{array}$ & $\begin{array}{l}6 \\
7 \\
8 \\
9\end{array}$ & $\begin{array}{r}0.4 \\
1.2 \\
2.9 \\
18.7\end{array}$ & $\begin{array}{l}12 \\
21 \\
25 \\
24\end{array}$ & $\begin{array}{l}1.705 \\
2.479 \\
2.516 \\
2.293\end{array}$ & $\begin{array}{r}198 \\
411 \\
506 \\
64\end{array}$ \\
\hline $\begin{array}{l}\text { Anchoa mitchilli } \\
\text { (bay anchovy) }\end{array}$ & -1 & 10 & 1.2 & 25 & 2.415 & 1445 \\
\hline $\begin{array}{l}\text { Eucinostomus } \\
\text { argenteus } \\
\text { (spotfin mojarra) }\end{array}$ & $\begin{array}{l}-1 \\
-2\end{array}$ & $\begin{array}{l}11 \\
12\end{array}$ & $\begin{array}{l}0.9 \\
1.5\end{array}$ & $\begin{array}{l}13 \\
12\end{array}$ & $\begin{array}{l}1.932 \\
1.718\end{array}$ & $\begin{array}{l}286 \\
384\end{array}$ \\
\hline $\begin{array}{l}\text { Eucinostomus gula } \\
\text { (silver jenny) }\end{array}$ & $\begin{array}{l}-1 \\
-2 \\
-3\end{array}$ & $\begin{array}{l}13 \\
14 \\
15\end{array}$ & $\begin{array}{l}1.5 \\
1.4 \\
4.2\end{array}$ & $\begin{array}{r}6 \\
13 \\
11\end{array}$ & $\begin{array}{l}1.280 \\
1.527 \\
0.811\end{array}$ & $\begin{array}{r}27 \\
181 \\
57\end{array}$ \\
\hline $\begin{array}{l}\text { Diplodus holbrooki } \\
\text { (spottail pinfish) }\end{array}$ & $\begin{array}{l}-1 \\
-2 \\
-3 \\
-4 \\
-5\end{array}$ & $\begin{array}{l}16 \\
17 \\
18 \\
19 \\
20\end{array}$ & $\begin{array}{r}0.2 \\
0.9 \\
1.3 \\
3.7 \\
42.4\end{array}$ & $\begin{array}{r}8 \\
15 \\
17 \\
21 \\
25\end{array}$ & $\begin{array}{l}1.625 \\
2.048 \\
1.639 \\
1.209 \\
1.331\end{array}$ & $\begin{array}{r}86 \\
418 \\
317 \\
399 \\
95\end{array}$ \\
\hline $\begin{array}{l}\text { Monacanthus } \\
\text { ciliatus } \\
\text { (fringed filefish) }\end{array}$ & $\begin{array}{l}-1 \\
-2 \\
-3\end{array}$ & $\begin{array}{l}21 \\
22 \\
23\end{array}$ & $\begin{array}{l}1.3 \\
1.6 \\
3.6\end{array}$ & $\begin{array}{l}17 \\
26 \\
22\end{array}$ & $\begin{array}{l}2.091 \\
2.191 \\
1.613\end{array}$ & $\begin{array}{c}198 \\
832 \\
33\end{array}$ \\
\hline $\begin{array}{l}\text { Monacanthus } \\
\text { hispidus } \\
\text { (planehead filefish) }\end{array}$ & $\begin{array}{l}-1 \\
-2 \\
-3\end{array}$ & $\begin{array}{l}24 \\
25 \\
26\end{array}$ & $\begin{array}{r}1.7 \\
5.0 \\
13.8\end{array}$ & $\begin{array}{l}13 \\
20 \\
22\end{array}$ & $\begin{array}{l}1.968 \\
1.943 \\
1.769\end{array}$ & $\begin{array}{r}67 \\
260 \\
22\end{array}$ \\
\hline $\begin{array}{l}\text { Syngnathus } \\
\text { scovelli } \\
\text { (gulf pipefish) }\end{array}$ & $\begin{array}{l}-1 \\
-2 \\
-3\end{array}$ & $\begin{array}{l}27 \\
28 \\
29\end{array}$ & $\begin{array}{l}1.1 \\
1.7 \\
4.0\end{array}$ & $\begin{array}{l}11 \\
11 \\
\text { I. D. }\end{array}$ & $\begin{array}{l}1.668 \\
1.631 \\
1.314\end{array}$ & $\begin{array}{r}46 \\
225 \\
20\end{array}$ \\
\hline $\begin{array}{l}\text { Syngnathus } \\
\text { floridae } \\
\text { (dusky pipefish) }\end{array}$ & $\begin{array}{l}-1 \\
-2 \\
-3\end{array}$ & $\begin{array}{l}30 \\
31 \\
32\end{array}$ & $\begin{array}{l}0.6 \\
1.3 \\
2.2\end{array}$ & $\begin{array}{l}\text { I. D. } \\
12 \\
11\end{array}$ & $\begin{array}{l}0.902 \\
1.319 \\
1.221\end{array}$ & $\begin{array}{r}15 \\
191 \\
669\end{array}$ \\
\hline $\begin{array}{l}\text { Bairdiella } \\
\text { chrysura } \\
\text { (silver perch) }\end{array}$ & $\begin{array}{l}-1 \\
-2 \\
-3\end{array}$ & $\begin{array}{l}33 \\
34 \\
35\end{array}$ & $\begin{array}{r}2.7 \\
5.2 \\
13.9\end{array}$ & $\begin{array}{l}\text { I. D } \\
21 \\
25\end{array}$ & $\begin{array}{l}1.833 \\
1.725 \\
1.833\end{array}$ & $\begin{array}{r}24 \\
617 \\
760\end{array}$ \\
\hline $\begin{array}{l}\text { Paraclinus fasciatus } \\
\text { (banded blenny) }\end{array}$ & -1 & 36 & 1.8 & 8 & 1.391 & 347 \\
\hline $\begin{array}{l}\text { Centropristis } \\
\text { melana (gulf } \\
\text { black sea bass) }\end{array}$ & $\begin{array}{l}-1 \\
-2 \\
-3\end{array}$ & $\begin{array}{l}37 \\
38 \\
39\end{array}$ & $\begin{array}{r}6.7 \\
20.5 \\
60.5\end{array}$ & $\begin{array}{l}11 \\
18 \\
15\end{array}$ & $\begin{array}{l}1.069 \\
1.438 \\
1.355\end{array}$ & $\begin{array}{r}69 \\
88 \\
166\end{array}$ \\
\hline $\begin{array}{l}\text { Orthopristis } \\
\text { chrysoptera } \\
\text { (pigfish) }\end{array}$ & $\begin{array}{l}-1 \\
-2 \\
-3 \\
-4\end{array}$ & $\begin{array}{l}40 \\
41 \\
42 \\
43\end{array}$ & $\begin{array}{l}0.2 \\
0.3 \\
1.2 \\
6.7\end{array}$ & $\begin{array}{l}\text { I. D. } \\
28 \\
35 \\
36\end{array}$ & $\begin{array}{l}1.506 \\
2.621 \\
1.331 \\
1.567\end{array}$ & $\begin{array}{r}290 \\
531 \\
152 \\
15\end{array}$ \\
\hline
\end{tabular}




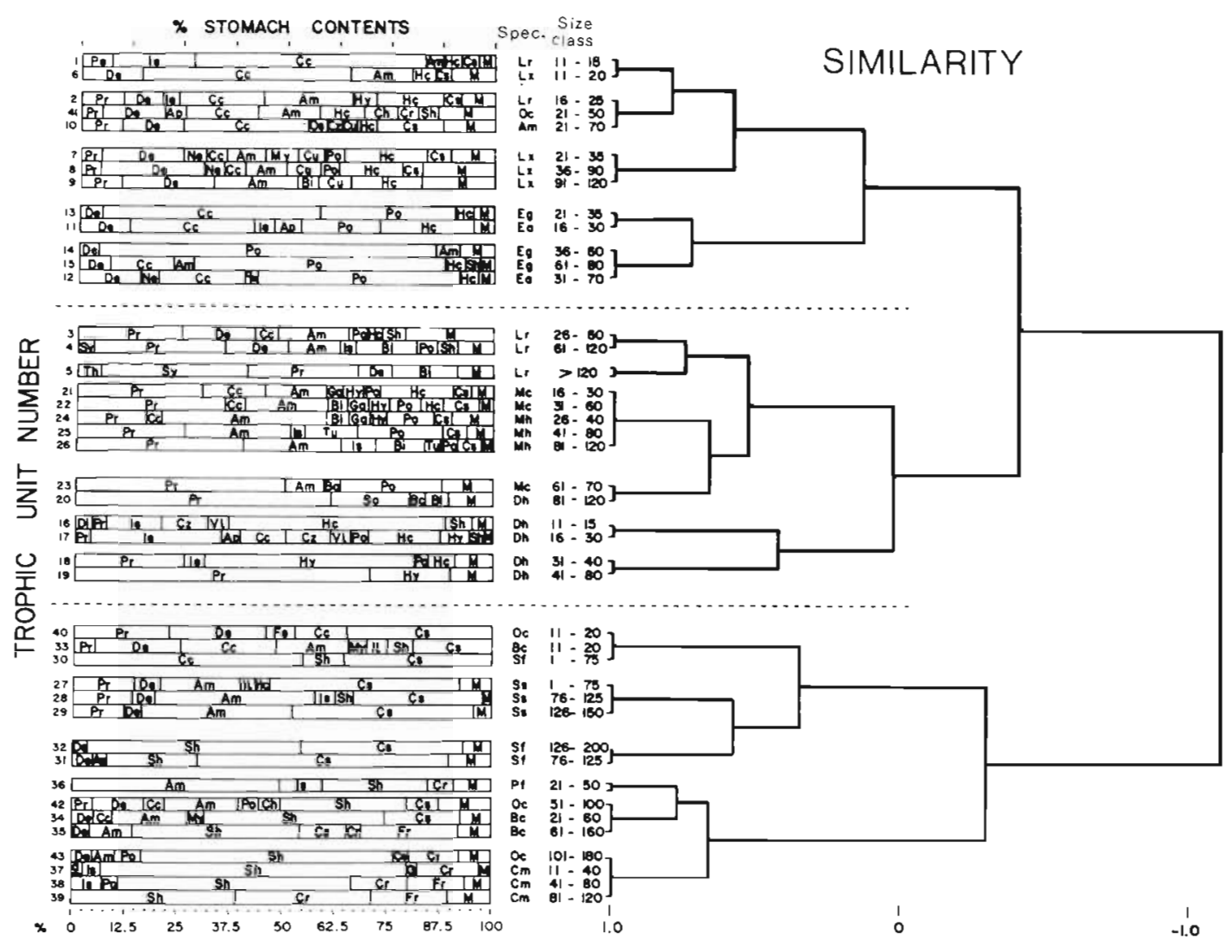

Fig. 2. Cluster analysis of 43 trophic units of fishes taken in Apalachee Bay from 1971 through 1977. All data are summed for all stations and sampling times with groups formed by similarity coefficients exceeding 0.80

on plant remains/detritus, planktonic copepods and other crustaceans during spring and fall. The syngnathids specialize on amphipods during late winter and spring (Syngnathus scovelli), and shrimp during the fall (Syngnathus floridae). Paraclinus fasciatus, with peak numbers during fall/winter, feeds largely on small crustaceans, while Centropristis melana, a summer dominant, feeds on shrimp, crabs, and fishes. Such patterns resemble those of the more advanced growth stages of Orthopristis chrysoptera and Bairdiella chrysura.

Several trends are evident in these data. Young stages of various species tend to feed on plant matter, detritus, and planktonic organisms, while further development is characterized by benthic feeding with species-specific trends of varying specialization. Taxonomic similarities of food habits are evident within groups such as the monacanthids and the syngnathids. Some species, such as Lagodon rhomboides and Diplodus holbrooki, go through temporally graded though distinct stages of feeding which include every major trophic level. Others, e.g. Anchoa mitchilli and Paraclinus fasciatus, do not have such distinct ontogenetic progressions. Species such as the monacanthids are relatively unisorm in prey choice, while others, e.g. Orthopristis chrysoptera, have a diverse diet with considerable intraspecific variability through time. While omnivory and detritivory are dominant features of the trophic response of fishes in the Apalachee Bay grassbeds, no single strategy prevails. There is little correlation with commonly used trophic levels (e.g. herbivory, primary carnivory) in many species, while, at the same time, there are widely divergent levels of specialization within and between species. There are thus distinct progressions of feeding response that, although varied, tend to follow certain well established lines of organization.

\section{Temporal Progressions of Trophic Response}

An analysis was made to determine the temporal relationships of the individual feeding units (Fig. 3). The seasonal abundance pattern of each ontogenetic trophic unit (averaged over the entire 8-year study period) was used to construct a 3-dimensional matrix of relative abundance. In general, most of the individual trophic units had narrow periods of high relative 

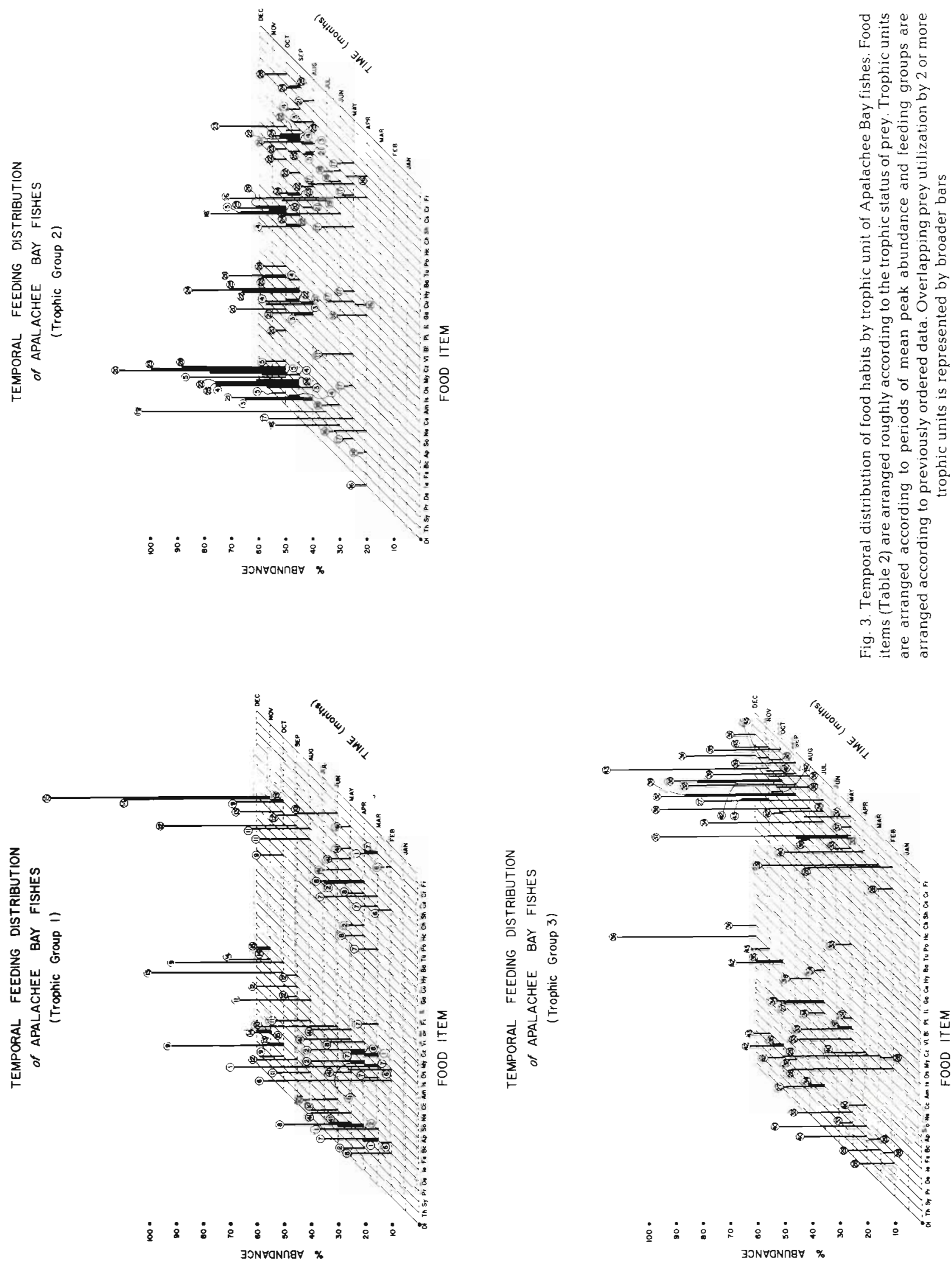


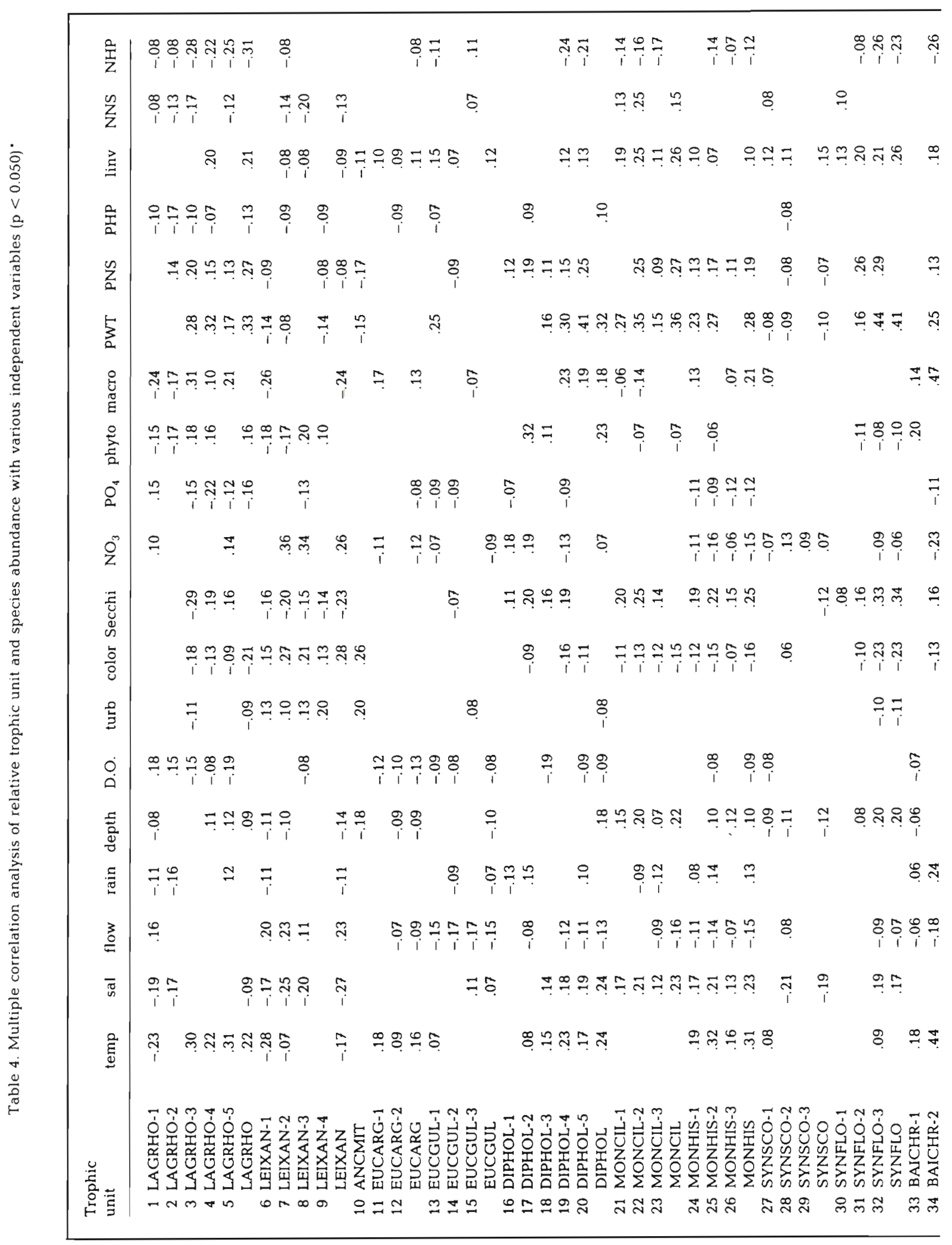




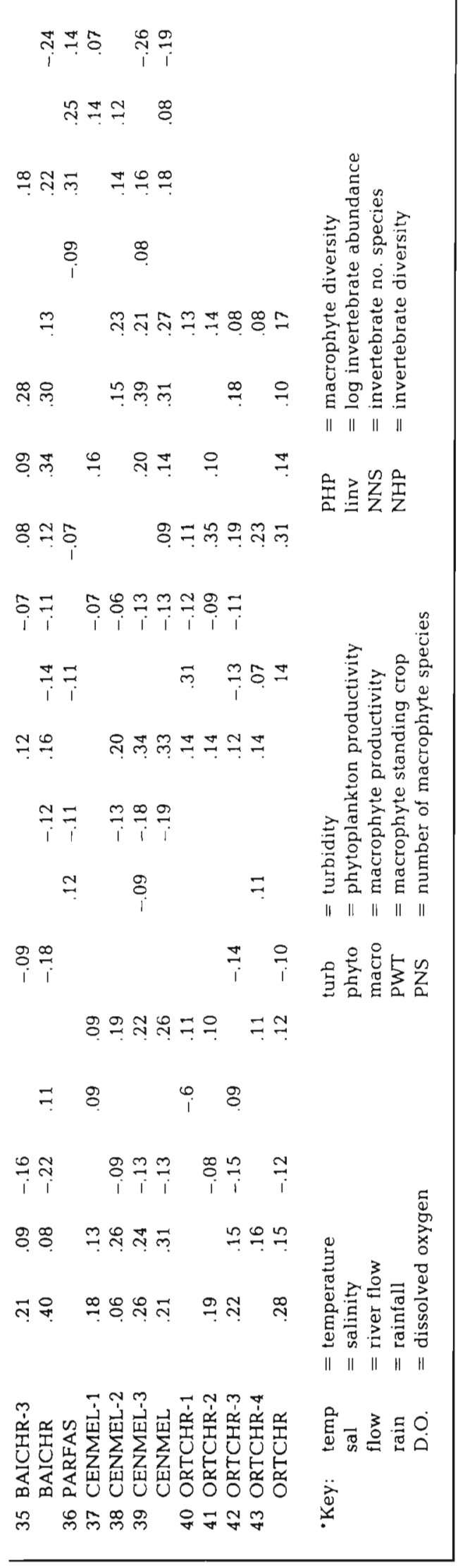

abundance although some overlap was noted. Fishes within Group I relied heavily on plant matter, planktonic organisms and polychaetes. There was relatively little overlap in diet, and those prey items taken by different trophic units were usually plant matter or planktonic forms. Some within-species overlap was noted, as might be expected since trophic unit delineation usually represented a stage in a continuous progression of ontogenetic food preference. Early stages of various species which specialize on planktonic and benthic copepods appeared to have no qualitative (species-specific) food preference, which would indicate a more generalized approach to feeding at this level of development.

There was evidence of partial overlap in food choices within the second trophic grouping. This was particularly true of the consumption of certain forms of plant matter, which is probably a non-limiting resource in the grassbeds during late summer/fall periods. During such periods, there are considerable die-offs of the benthic macrophytes, and organic detritus is abundant (Zimmerman and Livingston, $1976 a, 1976 b, 1979)$. Some of the dietary overlap occurred between closely related species. Other such overlaps included species-specific differentiation by pinfish and Diplodus holbrooki (Stoner and Livingston, unpubl.) which would be overlooked by a generalized analysis such as this one. Within the third group, there was some overlap in regard to feeding pressure on amphipods and shrimp. Generalized feeders tended to overlap during periods of increased food availability. This response may be related to spatial and temporal variability of specific habitat features of the seagrass beds, although this possibility remains untested by this particular analysis.

\section{Habitat Characteristics and Trophic Relationships}

To test for potential relationships between certain key habitat features and the trophic response of individual feeding units, a matrix was developed of station-by-month data concerning various physico-chemical variables, productivity estimates (phytoplankton, macrophytes; Bittaker, 1975), benthic plant features (standing crop, species richness, diversity; Zimmerman and Livingston, 1976a, b), benthic invertebrate distribution (relative abundance, species richness, diversity; Dugan, 1980; Greening, 1980), and the distribution of fish (trophic unit) numerical abundance. Relative abundance through time was broken down according to size classes as identified by the ontological trophic unit determinations. Multiple correlation analyses were carried out with individual trophic unit abundance and overall species abundance as the 
dependent variables and arranged as a matrix of independent correlation coefficients (Table. 4). These analyses were compared with stepwise and backward regressions with similar results. Each species had a distinctive response to habitat variability. The uniformly low correlation coefficients indicated that no single feature of the seagrass system controlled the relative abundance of a given trophic unit or species. Various species appeared to have changing habitat needs with time. For instance young pinfish migrated into the estuary during winter periods of high river flow and low temperature and salinity, when phytoplankton and macrophyte productivity was low (Zimmerman and Livingston, 1976b). With time, such relationships changed. Increased water temperature, macrophyte productivity, standing crop and species richness emerge as key variables during later stages of development. The species, taken as a single entity, did not reflect such changes in habitat needs with development. The generally low single unit correlations at any given time reflects problems associated with the considerable range of adaptibility of estuarine fishes to key environmental factors. On the other hand, when taken as a series of changes through time, the distinctive features of each species-specific strategy become more clearly defined. While important climatological features and associated water quality features appear to determine the broad habitat needs of a given trophic entity, the relatively strong interactions with biological features such as macrophyte productivity, standing crop, and multiple species interactions preclude a simple (deterministic) explanation of population distribution. Species with similar trophic needs such as spot, anchovies and plankton-feeding early stages of various species appear to have similar habitat relationships through time. There is no single set of habitat requirements for the dominant species in the seagrass beds.

In general, the overall trophic organization of seagrass fishes is largely dependent on interactions of individual feeding aggregations with seasonal progressions of key habitat features and productivity cycles; such relationships are defined through the incremental ontological response of individual growth stages, and appear to be related to combinations of changing habitat conditions and species-specific biological interactions.

\section{DISCUSSION}

Various studies in terrestrial (MacArthur, 1958; Schoener, 1968; Schoener and Gorman, 1968; Orians and Horn, 1969; Cody, 1974; Schoener, 1974) and aquatic (Zaret and Rand, 1971) areas have referred to the shared use of food and microhabitat. While there is evidence of increased trophic overlap with increased food abundance (Keast, 1965; Zaret and Rand, 1971; Werner and Hall, 1976), there is relatively little information concerning the influence of habitat changes on trophic relationships (Livingston, 1980; Stoner and Livingston, 1980). Chao and Musick (1977) ascribe the coexistence of predator fishes to differences in spatial/ temporal patterns of distribution, individual food habits and relative abundance. Habitat influences on food partitioning have been noted with sciaenids (Chao and Musick, 1977) and triglids (Ross, 1977). Various forms of resource partitioning have been demonstrated with freshwater fishes (Mendelson, 1975; Werner et al., 1977). Gascon and Leggett (1977) found more intense interspecific competition for food among fishes in less productive areas of certain lakes. Sheridan and Livingston (1979) report that estuarine fishes shared food resources in seasonal progressions, which appeared to follow relatively stable productivity cycles. Macpherson (1981) established that competition is more likely in benthic than in epibenthic guilds of marine fishes. This evidence indicates that food is an important mechanism of ecological segregation in various fish associations, and that past assumptions concerning demersal fishes simply as trophic generalists do not appear to be valid.

Coastal fishes go through ontogenetic progressions of 'distinct nutritional stages' (Damell, 1958; Carr and Adams, 1973; Kikuchi and Pérès, 1977; Adams, 1976a, b; Ross, 1978; Sheridan and Livingston, 1979; Stoner, 1980 b). As pointed out by Macpherson (1981), it can be argued that fish species may thus occupy various niches simultaneously with possible seasonal or diel patterns of resource partitioning. The results of this study indicate that species-specific ontogenetic feeding patterns do encompass various trophic levels but that this pattern is not universal within a given habitat. Moreover, the distinct segregation of benthic and epibenthic guilds (Macpherson, 1981) is not possible in shallow coastal areas since various species are functional components of both areas during their life histories. Use of the trophic unit appears to be one way to identify such feeding aggregations. Such analysis leads to the conclusion that diverse, coexisting feeding strategies are generally in synchrony with seasonal patterns of productivity and changes in key habitat characteristics. While there is a tendency for temporal partitioning of food resources in this situation, there is still considerable overlap in specific food items, such as plant remains and detritus, so that no generalized statement can be made concerning the role of competition and resource partitioning in the overall trophic organization. In this case, the temporally fluctuating supply of resources appears to be associated with seasonal progressions of food preferences within various 
species, and there is a wide range of strategies which tend to operate along restrictions imposed by the spatial and temporal dimensions of the habitat.

Models developed concerning the feeding strategies based on 'hunting' or 'grazing' (as reviewed by Stenseth, 1981) are difficult to apply in areas dominated by omnivores. Considering the broad diversity of food types and microhabitats utilized by grassbed fishes, it is difficult to differentiate a uniform model that can explain the trophic organization of seagrass fishes. While morphological constraints imposed by body form and mouth morphology may differentiate certain closely related species (Stoner and Livingston, unpubl.), there are indications that various coastal fishes have ontogenetic stages whose food preferences are timed with the availability of specific food types. Such temporal differentiation conflicts with a purely opportunistic approach to specific feeding strategies. When we are faced with the considerable diversity of feeding habits exhibited by grassbed fishes, it would appear that a spectral approach (Peters, 1977) without strict categorization according to narrow, speciesspecific trophic levels, would provide an alternative to the use of the species as an ecological entity in the determination of multispecies interactions.

In this study, the ontogenetic trophic unit appears to be useful in the differentiation of the response of individual species to seasonal progressions of productivity and habitat features in a seagrass system. This approach could help to explain problems concerning the lack of direct correlations of relative species abundance with particular combinations of physical factors. It would also put into question the established correlation of population abundance with individual habitat features in a given system. It could further provide a basis for experimental tests of hypotheses concerning differentiating mechanisms and the potential importance of competitive interactions in seagrass systems. While the history of food web interactions reflects many problems in the interpretation of spatial distribution of multi-species assemblages and resource utilization (Paine, 1980), there is little doubt that careful delineation of trophic interactions constitutes an important first step toward an understanding of the dynamic bases of community structure.

Acknowledgements. This work was carried out with the cooperation of various workers including $H$. S. Greening, J. D. Ryan, A. W. Stoner, and M. S. Zimmerman. Mr. G. C. Woodsum provided aid in the computer analysis of the data. The research was supported, in part, by Grant No. R-805288010 from the U.S. Environmental Protection Agency to R. J. Livingston.

\section{LITERATURE CITED}

Adams, S. M. (1976a). The ecology of eelgrass, Zostera marina (L.), fish communities. I. Structural analysis. J. exp. mar Biol. 22: 269-291
Adams, S. M. (1976b). Feeding ecology of eelgrass fish communities. Trans. am. Fish. Soc. 105: 514-519

Bittaker, H. F. (1975). A comparative study of the phytoplankton and benthic macrophyte primary productivity in a polluted versus an unpolluted coastal area. Master's thesis, Florida State University

Bray, R. N., Ebeling, A. W (1975). Food, activity, and habitat of three 'picker-type' microcarnivorous fishes in the kelp forests off Santa Barbara, California. Fish. Bull. 73: $815-829$

Brook, I. M. (1977). Trophic relationships in a seagrass community (Thalassia testudinum), in Card Sound, Florida. Fish diets in relation to Inacrobenthic and cryptic faunal abundance. Trans. Am. Fish. Soc. 106: 219-229

Carr, W. E. S., Adams, C. A. (1972). Food habits of juvenile marine fishes: evidence of the cleaning habit in the leatherjacket, Oligoplites saurus, and the spottail pinfish. Diplodus holbrooki. Fish. Bull. 70: 1111-1120

Carr, W. E. S., Adams, C. A. (1973). Food habits of juvenile marine fishes occupying seagrass beds in the estuarine zone near Crystal River, Florida. Trans. Am. Fish. Soc. 102: $511-540$

Chao, L. N., Musick, J. A. (1977). Life history, feeding habits, and functional morphology of juvenile sciaenid fishes in the York River Estuary, Virginia. Fish. Bull. 75: 657-702

Cody, M. L. (1974). Competition and structure of bird communities, Monographs in population biology, Princeton University Press

Darnell, R. M. (1958). Food habits of fishes and larger invertebrates of Lake Pontchartrain, Louisiana, an estuarine community. Publs Inst. mar Sci. Univ. Texas 5: 353-416

Darnell, R. M. (1961). Trophic spectrum of an estuarine community based on studies of Lake Pontchartrain. Louisiana. Ecology 42: 553-568

de Sylva, D. P. (1975). Nektonic food webs in estuaries. In: Cronin, L. E. (ed.) Estuarine research, Vol. 1. Academic Press, New York, pp. 420-447

Dugan, P. J. (1980). Long-term population changes of epibenthic macroinvertebrates in Apalachee Bay, Florida. M.S thesis, Florida State University, Tallahassee

Gascon, D., Leggett, W. C. (1977). Distribution, abundance, and resource utilization of littoral zone fishes in response to a nutrient/production gradient in Lake Memphremagog. J. Fish. Res. Bd Can. 34: 1105-1117

Greening, H. S. (1980). Seasonal and diel variations in the structure of macroinvertebrate communities: Apalachee Bay, Florida. M.S. thesis, Florida State University, Tallahassee

Hobson, E. S. (1978). Feeding relationships of teleostean fishes on coral reefs in Kona, Hawaii. Fish. Bull. 72: 915-1031

Hooks, T. A., Heck, K. L., Jr., Livingston, R. J. (1976). An inshore marine invertebrate community: structure and habitat associations in the northeastern Gulf of Mexico. Bull. mar. Sci. 26: 99-109

Keast, A. (1965). Resource subdivision amongst cohabiting fish species in a bay, Lake Opinicon, Ontario. Great Lakes Research Division, University of Michigan Publication 13: 106-132

Kikuchi, T., Pérès, J. M. (1977). Consumer ecology of seagrass beds. In: McRoy, C. P., Helffrich, C. (eds) Seagrass ecosystems: a scientific perspective. Marcel Dekker, Inc., New York and Basel, pp. 147-193

Lance, G. N., Williams, W T. (1967). A general theory of classificatory sorting strategies. I. Hierarchical systems. Comp. J. 9: 373-380

Livingston, R. J. (1975). Impact of kraft pulp-mill effluents on 
estuarine and coastal fishes in Apalachee Bay, Florida, USA. Mar. Biol. 32: 19-48

Livingston, R. J. (1980). Ontogenetic trophic relationships and stress in a coastal seagrass system in Florida. In: Kennedy, V. S. (ed.) Estuarine perspectives. Academic Press, pp. $423-435$

Livingston, R. J., Lloyd, R. S., Zimmerman, M. S. (1976a). Determination of sampling strategy for benthic macrophytes in polluted and unpolluted coastal areas. Bull. mar. Sci. 26: 569-575

Livingston, R. J., Thompson, N., Meeter, D. (1978). Long-term variation of organochlorine residues and assemblages of epibenthic organisms in a shallow north Florida (U.S.A.) estuary. Mar. Biol. 46: 355-372

Livingston, R. J., White, D. C., Iverson, R. L. (1976b). Energy relationships and the productivity of Apalachicola Bay. Florida Sea Grant Final Report

MacArthur, R. (1958). Population ecology of some warblers of northeastern coniferous forests. Ecology 39: 599-619

McEachran, J. D., Boesch, D. F., Musick, J. A. (1976). Food division within two sympatric species-pairs of skates (Pisces: Rajidae). Mar. Biol. 35: 301-317

MacPherson, E. (1981). Resource partitioning in a Mediterranean demersal fish community. Mar. Ecol. Prog. Ser. 4: 183-193

Matusita, K. (1955). Decision rules based on the distance for problems of fit, two samples and estimation. Ann. math. Statist. 26: 631-640

Meeter, D. A., Livingston, R. J. (1978). Statistical methods applied to a four-year multivariate study of a Florida estuarine system. In: Cairns, J., Dickson, K., Livingston, R. J. (eds.) Biological data in water pollution assessment: quantitative and statistical analyses. American Society for Testing and Materials STP 652, pp. 53-67

Mendelson, J. (1975). Feeding relationships among species of Notropis (Pisces: Cyprinidae) in a Wisconsin stream. Ecol. Monogr. 45: 199-230

Nie, N. H., Bent, D. H., Hull, C. H. (1970). Statistical package for the social sciences, McGraw Hill Book Co, England

Ogden, J. C. (1976). Some aspects of herbivore-plant relationships on Caribbean reefs and seagrass beds. Aquat. Bot. 2: $103-116$

Ogden, J. C., Lobel, P. S. (1978). The role of herbivorous fishes and urchins in coral reef communities. Env. Biol. Fish 3: $49-63$

Orians, G. H., Horn, H. S. (1969). Overlap in foods and foraging of four species of blackbirds in the potholes of central Washington. Ecology 50: 930-938

Paine, R. T. (1980). Food webs: linkage, interaction strength and community infrastructure. J. Anim. Ecol, 49: 667-685

Peters, R. H. (1977). The unpredictable problems of trophodynamics. Env. Biol. Fish 2: 97-101

Ross, S. T (1977). Patterns of resource partitioning in searobins (Pisces: Triglidae). Copeia 3: 561-571

Ross, S. T (1978). Trophic ontogeny of the leopard searobin, Prionotus scitulus (Pices: Triglidae). Fish. Bull. U.S. 76: 225-234

Schoener, T W. (1968). The Anolis lizards of Bimini: resource partitioning in a complex fauna. Ecology 49: 704-726

Schoener, T. W. (1974). Resource partitioning in ecological communities. Science, N.Y. 185: 27-39

Schoener, T. W., Gorman, G. C. (1968). Some niche differences in three Lesser Antillean lizards of the genus Anolis. Ecology 49: 819-830
Shannon, C. E., Weaver, W. (1963). The mathematical theory of communication, University of Illinois Press, Urbana

Sheridan, P. F. (1979). Trophic resource utilization by three species of sciaenid fishes in a northwest Florida estuary. Northeast Gulf Sci. 3: 1-15

Sheridan, P. F., Livingston, R. J. (1979). Cyclic trophic relations of fishes in an unpolluted, river-dominated estuary in north Florida. In: Livingston, R. J. (ed.) Ecological processes in coastal and marine systems. Plenum Press, New York, pp. 143-161

Sneath, P. H. A., Sokal, R. R. (1973). Numerical taxonomy, Freeman, San Francisco

Stenseth, N. C. (1981). Optimal food selection: some further considerations with special reference to the grazer-hunter distinction. Am. Nat. 117: 457-475

Stoner, A. W. (1979a). Species-specific predation on amphipod crustacea by the pinfish Lagodon rhomboides: Mediation by macrophyte standing crop. Mar. Biol. 55: 201-207

Stoner, A. W. (1979b). The macrobenthos of seagrass meadows in Apalachee Bay, Florida, and the feeding ecology of Lagodon rhomboides (Pisces: Sparidae). Ph.D. Dissertation, Florida State University, Tallahassee

Stoner, A. W. (1980a). The feeding ecology of the pinfish Lagodon rhomboides (Pisces: Sparidae): variation and functional responses. Fish. Bull., U.S. 78

Stoner, A. W. (1980b). The role of seagrass biomass in the organization of benthic macrofaunal assemblages. Bull. mar. Sci. Univ. Texas 23

Stoner, A. W., Livingston, R. J. (1980). Distributional ecology and food habits of the banded blenny Paraclinus fasciatus (Clinidae): a resident in a mobile habitat. Mar. Biol. 56: 239-246

Stoner, A. W., Livingston, R. J. (unpubl.). Ontogenetic variation in diet and feeding morphology in sympatric fishes of the family Sparidae from seagrass meadows

Strickland, J. D. H., Parsons, T. R. (1968). A practical handbook of seawater analysis. Bull. Fish. Res. Bd Can. 167: 1-311

Tyler, A. V. (1972). Food resource division among northern marine, demersal fishes. J. Fish. Res. Bd Can. 29: 997-1003

van Belle, G., Ahmad, I. (1974). Measuring affinity of distributions. In: Proschan, F., Serfling, R. (eds.) Reliability and biometry: statistical analysis of lifelength. Society for Industrial and Applied Mathematics, pp. 1-18

Werner, E. E., Hall, D. J. (1976). Niche shifts in sunfishes: experimental evidence and significance. Science, N. Y 191: 404-406

Werner, E. E., Hall, D. J., Laughlin, D. R., Wagner, D. J., Wilsmann, L. A., Funk, F. C. (1977). Habitat partitioning in a freshwater fish community. J. Fish. Res. Bd Can. 34: 360-370

Zaret, T. M., Rand, A. S. (1971). Competition in tropical stream fishes: support for the competitive exclusion principle. Ecology 52: 336-342

Zimmerman, M. S., Livingston, R. J. (1976a). The effects of kraft mill effluents on benthic macrophyte assemblages in a shallow bay system (Apalachee Bay, North Florida, U.S.A.). Mar. Biol. 34: 297-312

Zimmerman, M. S., Livingston, R. J. (1976b). Seasonality and physico-chemical ranges of benthic macrophytes from a north Florida estuary (Apalachee Bay). Contrib. mar Sci. Univ. of Texas 20:34-45

Zimmerman, M. S., Livingston, R. J. (1979). Dominance and distribution of benthic macrophyte assemblages in a north Florida estuary (Apalachee Bay, Florida). Bull. mar. Sci. 29: $27-40$ 